\title{
Effect of IL-15 addition on asbestos- induced suppression of human cytotoxic T lymphocyte induction
}

Naoko Kumagai-Takei ${ }^{1}$, Yasumitsu Nishimura ${ }^{1 *}$ (D), Hidenori Matsuzaki ${ }^{1,2}$, Suni Lee ${ }^{1}$, Kei Yoshitome ${ }^{1}$, Tatsuo Ito ${ }^{1}$ and Takemi Otsuki ${ }^{1}$

\begin{abstract}
Background: Asbestos fibers possess tumorigenicity and are thought to cause mesothelioma. We have previously reported that exposure to asbestos fibers causes a reduction in antitumor immunity. Asbestos exposure in the mixed lymphocyte reaction (MLR) showed suppressed induction of cytotoxic T lymphocytes (CTLs), accompanied by a decrease in proliferation of $C D 8^{+} T$ cells. Recently, we reported that asbestos-induced suppression of CTL induction is not due to insufficient levels of interleukin-2 (IL-2). In this study, we continue to investigate the mechanism responsible for the effect of asbestos fibers on the differentiation of CTLs and focus on interleukin-15 (IL-15) which is known to be a regulator of T lymphocyte proliferation.

Methods: For MLR, human peripheral blood mononuclear cells (PBMCs) were cultured with irradiated allogenic PBMCs upon exposure to chrysotile B asbestos at $5 \mu \mathrm{g} / \mathrm{ml}$ for 7 days. After 2 days of culture, IL-15 was added at 1 $\mathrm{ng} / \mathrm{ml}$. After 7 days of MLR, PBMCs were collected and analyzed for phenotypic and functional markers of CD $8^{+} \mathrm{T}$ cells with fluorescence-labeled anti-CD3, anti-CD8, anti-CD45RA, anti-CD45RO, anti-CD25, and anti-granzyme B antibodies using flow cytometry. To examine the effect of IL-15 on the expression level of intracellular granzyme $B$ in proliferating and non-proliferating $\mathrm{CD}^{+}$lymphocytes, PBMCs were stained using carboxyfluorescein diacetate succinimidyl ester (CFSE) and then washed and used for the MLR.
\end{abstract}

Results: IL-15 addition partially reversed the decrease in $\mathrm{CD}^{+} \mathrm{CD}^{+}$cell numbers and facilitated complete recovery of granzyme $B^{+}$cell percentages. IL-15 completely reversed the asbestos-induced decrease in percentage of granzyme $\mathrm{B}^{+}$cells in both non-proliferating CFSE-positive and proliferating CFSE-negative CD8 ${ }^{+}$cells. The asbestosinduced decrease in the percentage of $\mathrm{CD}_{2} 5^{+}$and $\mathrm{CD} 45 \mathrm{RO}^{+}$cells in $\mathrm{CD} 8^{+}$lymphocytes was not reversed by IL-15.

Conclusion: These findings indicate that CTLs induced upon exposure to asbestos possess dysfunctional machinery that can be partly compensated by IL-15 supplementation, and that IL-15 is more effective in the recovery of proliferation and granzyme B levels from asbestos-induced suppression of CTL induction compared with IL-2.

Keywords: Asbestos, CTL, IL-15, Proliferation, Granzyme B

\footnotetext{
* Correspondence: yas@med.kawasaki-m.ac.jp

'Department of Hygiene, Kawasaki Medical School, Kurashiki 701-0192, Japan

Full list of author information is available at the end of the article
}

(C) The Author(s). 2021 Open Access This article is licensed under a Creative Commons Attribution 4.0 International License, which permits use, sharing, adaptation, distribution and reproduction in any medium or format, as long as you give appropriate credit to the original author(s) and the source, provide a link to the Creative Commons licence, and indicate if changes were made. The images or other third party material in this article are included in the article's Creative Commons licence, unless indicated otherwise in a credit line to the material. If material is not included in the article's Creative Commons licence and your intended use is not permitted by statutory regulation or exceeds the permitted use, you will need to obtain permission directly from the copyright holder. To view a copy of this licence, visit http://creativecommons.org/licenses/by/4.0/ The Creative Commons Public Domain Dedication waiver (http://creativecommons.org/publicdomain/zero/1.0/) applies to the data made available in this article, unless otherwise stated in a credit line to the data. 


\section{Background}

Exposure to asbestos can lead to tumor diseases such as malignant mesothelioma and lung cancer $[1,2]$. Although the use of asbestos has now been prohibited in 55 countries, these prohibitions have only recently been enacted and therefore have not yet had a measureable impact on the incidence of asbestos-related diseases. Asbestos exposure in the developed world has been greatly reduced or eliminated in industrial operations; however, exposure still occurs from asbestos remaining in existing buildings, old industrial sites and from naturally occurring asbestos [3]. There are numerous countries in Asia that continue to mine, import, and use this fiber. Although the first phase to ban the use of asbestos in Japan was announced in 2004, asbestos-related disease is widespread [4]. Japan is currently experiencing an increase in mesothelioma, and rates are predicted to peak sometime between 2030 and 2039 [3]. In the USA, despite the decrease in age-adjusted mesothelioma incidence rates in the past decades, approximately 3000 incident cases of mesothelioma are registered each year. The overall number of new cases and of deaths per year caused by mesothelioma continues to steadily increase in many countries where populations are becoming older since mesothelioma affects mostly older people. The highest age-standardized incidence rates in 2018 were observed in the USA, Australia, Russia, Western Europe, Turkey, South Africa, and Argentina according to the World Health Organization [5].

Mutagenicity or carcinogenicity of asbestos is believed to cause malignant mesothelioma. Chromosomal changes, DNA damage, and oxidative DNA lesions occur in mesothelial cells which cultured upon exposure to asbestos fibers at cytotoxic concentrations $[6,7]$. The onset of malignant mesothelioma is not rapid following exposure of asbestos, but rather requires a long elapsed time [8-10]. This suggests the possibility that the body might be protected from malignant mesothelioma by antitumor immunity, functional insufficiency of which might be caused by exposure to asbestos and related with the onset of mesothelioma. In our previous study based on this hypothesis, it was found that asbestos exposure changes the expression pattern of activating receptors on human NK cells and the functions of $\mathrm{CD}^{+} \mathrm{T}$ cells $[11,12]$.

Previously, we reported that asbestos exposure suppressed the differentiation of human mature cytotoxic $\mathrm{T}$ lymphocytes (CTLs) in the mixed lymphocyte reaction (MLR) and was accompanied by a decrease in the proliferation of immature CTLs [13]. CD8 ${ }^{+}$lymphocytes in culture following exposure to asbestos showed impaired cytotoxicity with decreases in the proliferation and percentage of $\mathrm{CD}_{2} 5^{+}$and $\mathrm{CD}_{45 \mathrm{RO}^{+}}$cells in $\mathrm{CD}^{+}$ lymphocytes and an increase in percentage of CD45RA ${ }^{+}$ cells compared with control cultures. Recently, we focused on investigating the mechanism of the asbestos-induced suppressed differentiation of mature CTLs with the decrease in the proliferation of $\mathrm{CD}^{+}$lymphocytes and demonstrated that the phenomenon was not attributed to insufficient production of interleukin-2 (IL-2) since exogenous supplementation of IL-2 could augment the cytotoxicity of asbestos-exposed $\mathrm{CD}^{+}$lymphocytes and percentage of granzyme $\mathrm{B}^{+}$cells but did not restore any other parameters [14]. IL-2 and IL-15 share some functions as a consequence of their utilization of the IL-2R $\beta$ subunit and common $\gamma$-chain [15]. It is also considered that interleukin-15 (IL-15) is involved in initiation of the $\mathrm{T}$ cell response to an antigen presented by dendritic cells (DCs), such that substantial $\mathrm{T}$ cell clonal expansion is driven following $\mathrm{T}$-cell receptor ligation of peptide-MHC, after which time IL-15 plays a role in the generation and maintenance of memory $\mathrm{T}$ cells [16]. Therefore, in the present study, we focused on investigating the effect of IL15 addition on asbestos-induced suppression of mature CTL differentiation with decreased proliferation of immature CTLs. We set out to determine whether IL-15 addition might reverse the suppressed induction of CTLs following exposure to asbestos. The production of IL-15 in the MLR was examined, and the effect of adding IL-15 to the culture at $1 \mathrm{ng} / \mathrm{ml}$ on the second day of the MLR was investigated with respect to suppressed CTL differentiation in cultures exposed to chrysotile B (CB) asbestos.

\section{Methods \\ Cell preparation}

PBMCs were separated from heparinized blood obtained from healthy donors using a Ficoll-Hypaque density gradient (Separate-L, Muto Pure Chemicals Co. Ltd., Tokyo, Japan). Freshly isolated PBMCs were suspended in RPMI 1640 medium (Sigma-Aldrich, St. Louis, MO, USA) supplemented with $10 \%$ heat-inactivated fetal bovine serum (Medical and Biological Laboratories Co., Ltd., Nagoya, Japan), $100 \mu \mathrm{g} / \mathrm{ml}$ streptomycin, and $100 \mathrm{U} / \mathrm{ml}$ penicillin (Meiji Seika Pharma Co., Ltd., Tokyo, Japan), as previously described [14].

\section{MLRs}

For the MLRs, PBMCs were stimulated with allogenic PBMCs (PBMCs:allogenic PBMCs ratio $=1.5 \times 10^{5}: 5.0 \times$ $10^{4}$ ), that had been treated with irradiation of $40 \mathrm{~Gy}$ according to a previous method [17]. Some of the MLRs were performed in the presence of $\mathrm{CB}$ asbestos at $5 \mu \mathrm{g}$ / ml. Following 2 days of the MLRs with CB, IL-15 (Peprotec, Rocky Hill, NJ, USA) was added at $1 \mathrm{ng} / \mathrm{ml}$ for 5 days. International Union Against Cancer (UICC) standard CB was kindly provided by the Department of Occupational Health at the National Institute for Occupational Health of South Africa [18]. 


\section{ELISA}

Culture supernatants were collected at days $0,2,4$, and 7 after the MLR, and assayed for the production of IL-15 using a Quantikine ELISA kit (R\&D Systems, Inc. Minneapolis, MN, USA).

\section{Assay for cell surface expression levels}

To examine the expression level of molecules on the cell surface, cells harvested after the MLR were washed with PBS containing 2\% FBS and then stained with the following antibodies (Abs): phycoerythrin-cychrome 5 (PC5)-conjugated anti-CD8 (Beckman Coulter, Inc., Brea, CA, USA) and fluorescein isothiocyanate (FITC)-conjugated anti-CD3, phycoerythrin (PE)-conjugated anti-CD4, FITC-conjugated anti-CD25 (Becton Dickinson, Franklin Lakes, NJ, USA), PE-conjugated anti-CD45RA, or PEconjugated anti-CD45RO (BioLegend, San Diego, CA, USA) at room temperature in the dark for $30 \mathrm{~min}$. Cells were then washed with PBS containing $2 \%$ FBS and resuspended in $0.3 \mathrm{ml}$ of PBS containing 2\% FBS for analysis by flow cytometry (FCM) using FACS Calibur ${ }^{\mathrm{TM}}$ (Becton Dickinson) as previously described [14].

\section{Assay for intracellular expression levels}

To examine the expression level of intracellular granzyme B, cells were harvested after the MLR, and surfaces were stained with PC5-conjugated anti-CD8 Ab as described above. Surface-stained cells were washed with PBS containing 2\% FBS and then fixed with 3.7\% formaldehyde for $15 \mathrm{~min}$. Fixed cells were washed with PBS containing $2 \%$ FBS. Fixed cells were permeabilized with $0.1 \%$ Triton 100 and stained with R-phycoerythrin (RPE)conjugated anti-granzyme B Ab (AbD Serotec, Oxford, UK) at room temperature in the dark for $30 \mathrm{~min}$ as previously described [14]. Cells were then washed and resuspended as described above. The percentage of cells positive for each parameter was analyzed using FCM.

\section{Assay for granzyme B production in proliferating and non-proliferating $\mathrm{CD}^{+}$lymphocytes}

To examine the effect of IL-15 on the expression level of intracellular granzyme $\mathrm{B}$ in proliferating and nonproliferating $\mathrm{CD}^{+}$lymphocytes, PBMCs were stained using CFSE (Molecular Probes, Inc., Eugene, OR, USA) and then washed and used for the MLR as previously described [14]. Following the MLR, cells were harvested and stained with PC5-conjugated anti-CD8 and RPEconjugated anti-granzyme $\mathrm{B}$ Abs as described above. The percentage of granzyme $\mathrm{B}^{+}$cells in proliferating CFSE-negative $\mathrm{CD} 8^{+}$lymphocytes or non-proliferating CFSE-positive $\mathrm{CD}^{+}$cells was analyzed using FACS Aria $^{\mathrm{TM}}$ (Becton Dickinson).

\section{Statistical analysis}

Significance of difference $(p<0.05)$ was determined using an analysis of variance with the post hoc test of Student-Newman-Keuls or paired Student's $t$ test.

\section{Results}

Effect of chrysotile B asbestos exposure on secreted production of IL-15 during the MLR

Supernatants from cultures of peripheral blood mononuclear cells (PBMCs) with allogenic stimulation in the absence or presence of $\mathrm{CB}$ asbestos were harvested and compared for their capacity to produce IL-15 at days 2, 4, and 7 after the MLR. For part of the cultures, PBMCs were cultured alone and supernatants were used as a group without allogenic stimulation. However, secreted IL-15 could not be detected even in the control culture with allogenic stimulation as well as the group without allogenic stimulation at days 2, 4, and 7 in all of the 4 experiments (Fig. 1). In the CB-exposed cultures, production of IL-15 was also not detected. Thus, there were no measurable IL15 levels in any of the culture supernatants regardless of the absence or presence of exposure to $\mathrm{CB}$. These results indicate the possibility that IL-15 was not produced in these cultures at the level detectable by ELISA.

\section{Effect of IL-15 on percentage and number of $\mathrm{CD}^{+} \mathrm{CD}^{+}$,} $\mathrm{CD}^{+} \mathrm{CD}^{+}$, and $\mathrm{CD} 3$-negative cells in PBMCs

IL-15 was added into the asbestos-exposed culture at day 2 after the MLR, since our previous study showed that the number of carboxyfluorescein diacetate succinimidyl ester (CFSE)-negative cells, that is cells which are proliferating or reaching the end of proliferation, increased markedly in $\mathrm{CD}^{+}$lymphocytes stimulated with allogenic PBMCs from day 6 to day 7 of the MLR [13]. At day 7 , cells were harvested and the percentage and number of $\mathrm{CD}^{+} \mathrm{CD}^{+}$cells were measured. While the

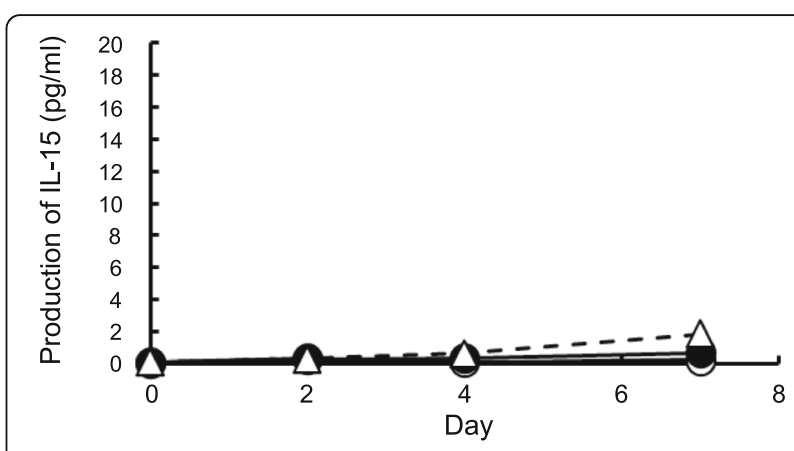

Fig. 1 Production of IL-15 during the MLR following exposure to asbestos. Levels of IL-15 in the supernatant of cultures was determined by ELISA at 0, 2, 4, and 7 days after the MLR. Culture supernatants were harvested from the three groups, representing no stimulation (open circle), allogenic stimulation (closed circle), and CB exposed with allogenic stimulation (open triangle). Data represent the mean from four independent experiments using PBMCs from three individuals 
percentage of $\mathrm{CD}^{+} \mathrm{CD}^{+}$cells did not decrease (Fig. 2a), exposure to $\mathrm{CB}$ caused a significant decrease in the number of $\mathrm{CD}^{+} \mathrm{CD}^{+}$cells, as we previously reported (Fig. 2b). The addition of IL-15 significantly restored the asbestos-induced decrease in the number of $\mathrm{CD}^{+} \mathrm{CD}^{+}$ cells (Fig. 2b), which differed from the effect of IL-2 addition [14]. However, the mean value of the IL-15treated group was intermediate between the groups with and without $\mathrm{CB}$ exposure, meaning that IL-15 addition did not completely restore cell numbers. Although the percentage of $\mathrm{CD}^{+} \mathrm{CD}^{+}$and $\mathrm{CD} 3$-negative cells as well as $\mathrm{CD}^{+}{ }^{-} \mathrm{CD}^{+}$cells did not decrease (Fig. 2c and e), exposure to $\mathrm{CB}$ caused a significant decrease in the number of $\mathrm{CD}^{+} \mathrm{CD}^{+}{ }^{+}$and $\mathrm{CD} 3$-negative cells (Fig. 2d and f). The addition of IL-15 significantly restored the asbestosinduced decrease in the number of $\mathrm{CD}^{+} \mathrm{CD} 8^{+}$cells, but not $\mathrm{CD}^{+} \mathrm{CD}^{+}{ }^{+}$or $\mathrm{CD} 3$-negative cell numbers (Fig. 2d and $\mathrm{f}$ ). These results indicate that exogenously added IL-15 could, to some extent, complement the effect on $\mathrm{CB}$-exposed cultures to maintain the number of $\mathrm{CD}^{+} \mathrm{CD}^{+}$cells.

\section{Effect of IL-15 on differentiation of naïve $\mathrm{CD}^{+} \mathrm{T}$ cells into CTLS}

In an effort to determine whether asbestos-induced suppression of naïve $\mathrm{CD}^{+} \mathrm{T}$ cell differentiation into effector/memory cells could be restored in response to exogenously added IL-15, the percentage of cells positive for the following markers was measured at day 7 after the MLR: CD45RA and CD45RO, expressed on naïve and effector/memory cells, respectively $[19,20]$, as well as CD25 cells, expressed on activated cells [21]. Exposure to $\mathrm{CB}$ resulted in an increase in $\mathrm{CD} 45 \mathrm{RA}^{+}$naïve cells in $\mathrm{CD}^{+}$lymphocytes stimulated with allogenic PBMCs, and a decrease in $\mathrm{CD} 45 \mathrm{RO}^{+}$effector/memory cells and CD $25^{+}$activated cells in $\mathrm{CD}^{+}$lymphocytes (Fig. 3a and b). This is consistent with our previous findings in that the present study could also demonstrate suppressed differentiation into CTLs following exposure to asbestos [13]. Despite the complementary effect of IL-15 on $\mathrm{CD}^{+} \mathrm{CD}^{+}$cell number as mentioned above, suppression of increased levels of $\mathrm{CD}_{2} 5^{+}$and $\mathrm{CD} 45 \mathrm{RO}^{+}$cells in $\mathrm{CD} 8^{+}$ lymphocytes and suppressed decrease in $\mathrm{CD}_{4} 5 \mathrm{RA}^{+}$cell levels were not restored by the addition of IL-15. These results indicate that appropriate differentiation of CTLs following exposure to $\mathrm{CB}$ during the MLR was not achieved by exogenously added IL-15.

\section{Effect of IL-15 on percentage of granzyme B-positive cells in $\mathrm{CD}^{+}$lymphocytes}

We examined intracellular granzyme $\mathrm{B}$ in $\mathrm{CD}^{+}$lymphocytes. Granzyme B is a representative mediator of target cell death accomplished by CTLs. Allogenic stimulation induced an increase in the percentage of granzyme $\mathrm{B}^{+}$ cells in $\mathrm{CD}^{+}$lymphocytes, whereas exposure to $\mathrm{CB}$ suppressed this increase in the percentage of granzyme $\mathrm{B}^{+}$cells, which is consistent with our previous findings [13]. The addition of IL-15 could diminish that suppression, whereby the percentage of granzyme $\mathrm{B}^{+}$cells did not differ between the control and IL-15-treated culture with CB. These results indicate that exogenously added IL-15 could fully restore the asbestos-induced decrease in percentage of granzyme $\mathrm{B}^{+}$cells (Fig. $4 \mathrm{a}$ and $\mathrm{b}$ ).

Effect of IL-15 on induction of granzyme B in proliferating and non-proliferating $\mathrm{CD}^{+}$lymphocytes

As mentioned above, although the asbestos-induced decrease in number of $\mathrm{CD}^{+}$lymphocytes following allogenic stimulation was restored by the addition of IL-15, the effect was incomplete (Fig. 2). Therefore, we set out to determine whether the restored increase in the number of $\mathrm{CD}^{+}$lymphocytes induced by the addition of IL15 might be due to recovery of cell proliferation. Additionally, we examined whether the restored increase in granzyme $\mathrm{B}^{+}$cell levels induced by the addition of IL-15 might be accompanied by the recovery of cell proliferation. PBMCs were stained using CFSE before the MLR to detect CFSE-negative proliferating cells. After 7 days of the MLR, PBMCs were collected and stained using granzyme $\mathrm{B}$ and $\mathrm{CD} 8$ antibodies (Abs). Exposure to $\mathrm{CB}$ suppressed the proliferation of $\mathrm{CD}^{+}$lymphocytes stimulated with allogenic PBMCs, as was found in our previous studies [13]. As shown in Fig. 5a, addition of IL-15 significantly restored the asbestos-induced suppression of $\mathrm{CD}^{+}$lymphocyte proliferation during the MLR; however, the restored level was lower than that of the control culture without CB. As shown in Fig. 5 b-d , exposure to $\mathrm{CB}$ tended to result in a decrease in the percentage of CFSE-negative (proliferating) and granzyme B-positive cells $(p=0.062)$, although the CFSE-positive (non-proliferating) and granzyme B-positive cells in $\mathrm{CD} 8^{+}$lymphocytes did not decrease following exposure to $\mathrm{CB}$. Additionally, the percentage of both proliferating and non-proliferating granzyme B-positive cells upon asbestos exposure increased significantly following the addition of IL-15. These results indicate that exogenously added IL-15 led to partial recovery of the asbestosinduced suppression of cell proliferation, and furthermore restored and enhanced intracellular granzyme B in both proliferating and non-proliferating $\mathrm{CD} 8^{+}$lymphocytes exposed to asbestos.

\section{Discussion}

Previously, we reported that asbestos exposure suppressed the differentiation of mature CTLs and was accompanied by a decrease in the proliferation of immature CTLs [13]. Then we examined the effect of IL-2 addition on asbestos-induced suppression of CTL 


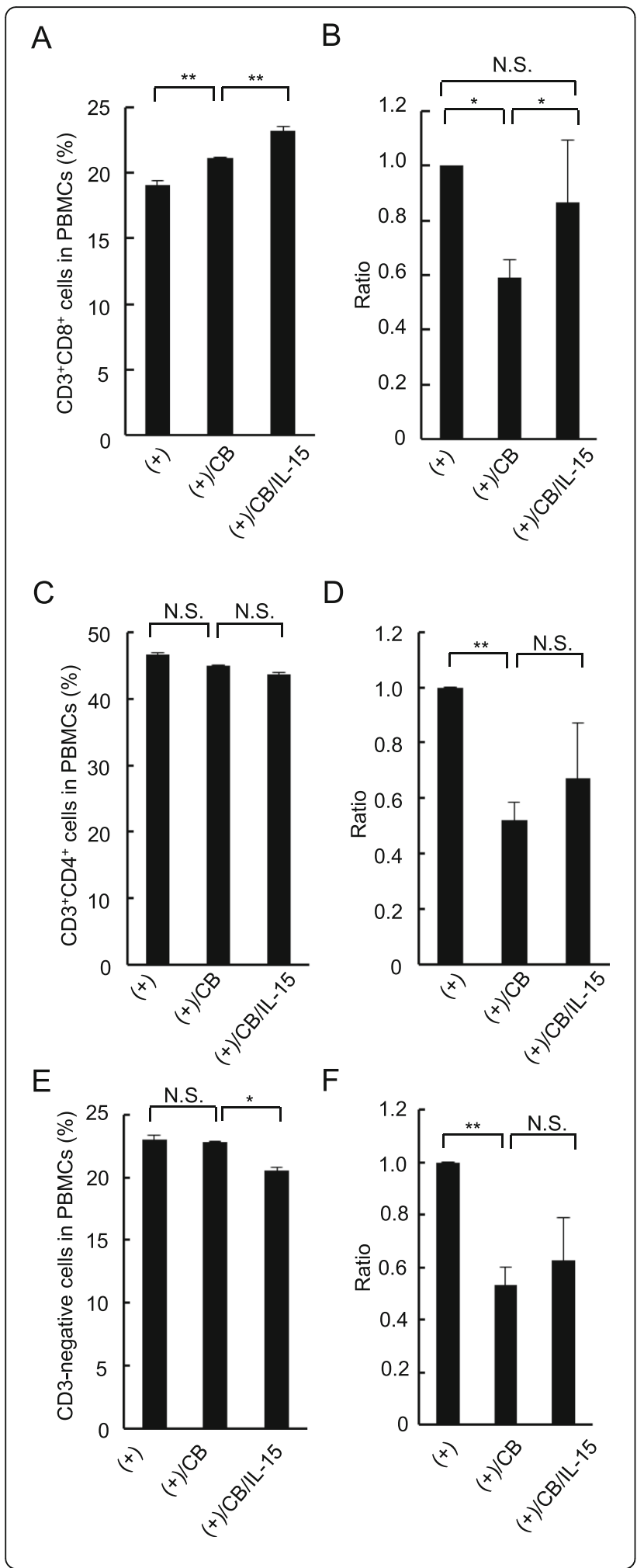

Fig. 2 The percentage and number of $\mathrm{CD}^{+} \mathrm{CD}^{+}, \mathrm{CD}^{+} \mathrm{CD} 4^{+}$, and CD3-negative cells during the induction of effector CTL by MLR. PBMCs were cultured with stimulation of irradiated allogenic PBMCs under exposure to asbestos with or without addition of IL-15. The percentage of $\mathrm{CD}^{+} \mathrm{CD}^{+}, \mathrm{CD}^{+} \mathrm{CD}^{+}$, and $\mathrm{CD} 3$-negative cells in harvested PBMCs was measured by FCM (a, $\mathbf{c}$, and $\mathbf{e})$, and the cell number of those per 10 well was calculated and shown as the ratio to the value of control group which stimulated allogenically but not exposed to asbestos or supplemented with IL-15 (b, d, and $\mathbf{f}$ ). Data are obtained from three independent experiments and are shown as the mean + SD. Significant differences are marked with asterisks ( ${ }^{*} p$ $\left.<0.05,{ }^{* *} p<0.01\right)$. No significant difference is indicated by N.S.. The control group is represented by $(+)$, the group cultured with allogenic PBMCs under exposure to $\mathrm{CB}$ is represented by $(+) / \mathrm{CB}$, and the group cultured with allogenic PBMCs under $C B$ exposure with IL-15 is represented by (+)/CB/IL-15

induction [14]. Although exogenously added IL-2 suppressed the decrease in intracellular granzyme B, the effect was only partial. Furthermore, the addition of IL-2 could not restore other alterations in cell numbers of $\mathrm{CD}^{+} \mathrm{CD}^{+}$or expression levels of cell surface markers. In the present study, we found that addition of IL-15 led to full recovery of the percentage of granzyme $\mathrm{B}$ and partial recovery of proliferation of $\mathrm{CD}^{+}$lymphocytes in contrast to IL-2 addition, although it did not restore the percentage of $\mathrm{CD}_{4} 5 \mathrm{RA}^{+}, \mathrm{CD}_{4} 5 \mathrm{RO}^{+}$, or $\mathrm{CD} 25^{+}$cells in $\mathrm{CD}^{+}$lymphocytes after the MLR. These findings indicate that supplementation with IL-15 has the potential to improve the suppressed function of CTLs following exposure to asbestos, although it did not restore the asbestos-induced suppression of mature CTL differentiation following antigen stimulation. Thus, the present study demonstrated that IL-15 is more effective in the recovery of cell proliferation and granzyme B levels following asbestos-induced suppression of CTL induction compared with IL-2.

Unfortunately, secreted IL-15 was not detected via ELISA in the present study, although it is extremely difficult to detect secreted IL-15 protein in the supernatants of cultured cells that express IL-15 mRNA in the published study [22]. Therefore, we could not conclude that an insufficient level of IL-15 is not the predominant cause for the suppressed induction of CTLs following asbestos exposure. Nevertheless, the present study demonstrated that CTLs induced upon exposure to asbestos possess dysfunctional machinery that can be partly compensated by IL- 15 supplementation. It is known that asbestos fibers inhaled occupationally or environmentally accumulate in lymph nodes [23, 24], which means that our observation regarding dysfunction in CTLs caused by asbestos could also be relevant to in vivo conditions. Several studies using animals have demonstrated the relationship between IL-15 deficiency and malignant diseases. HER2/neu transgenic mice with homozygous knockout of IL-15 (IL15KO/NeuT mice) were compared 


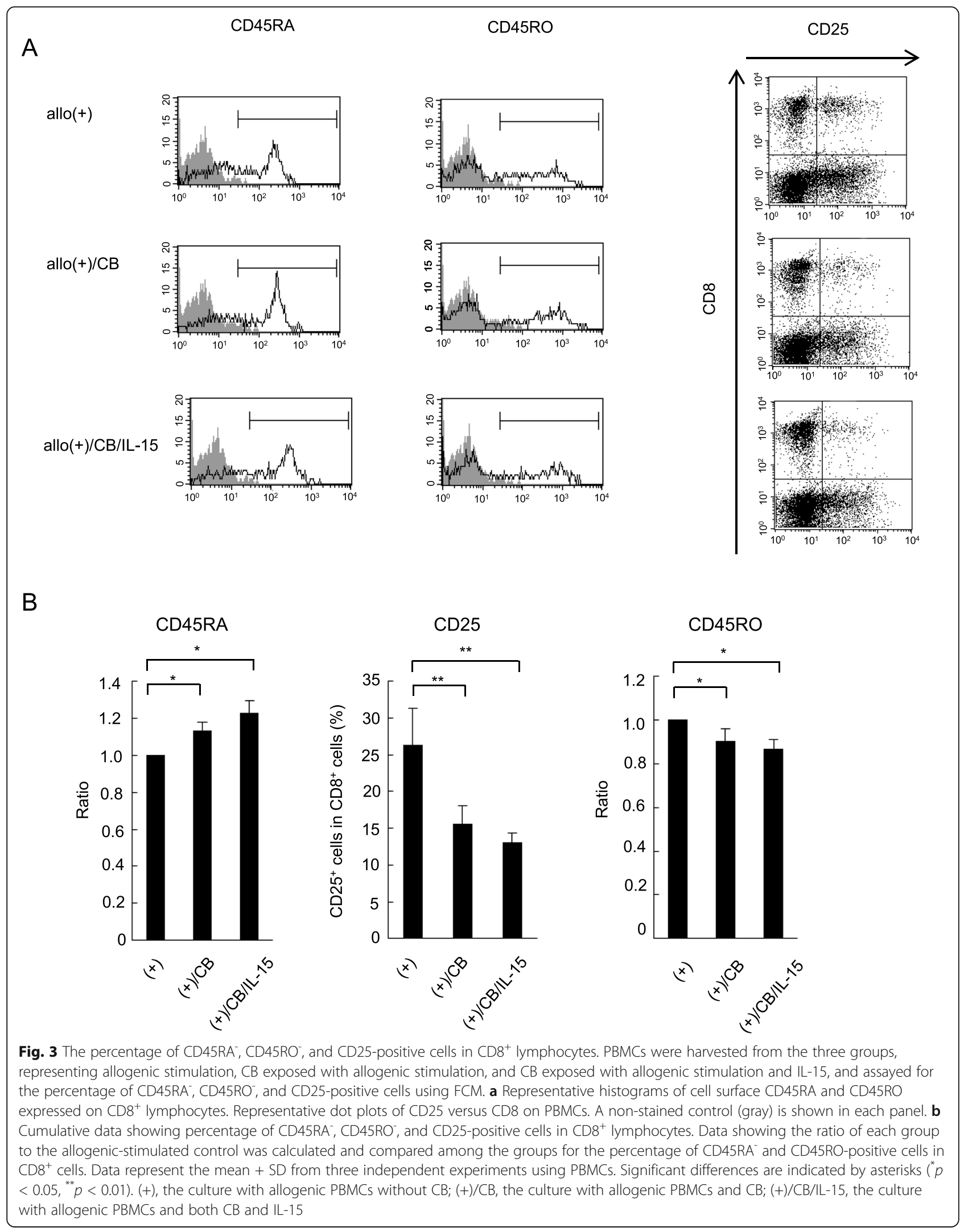


A allo(+)

allo(+)/CB

allo(+)/CB/IL-15
Granzyme B
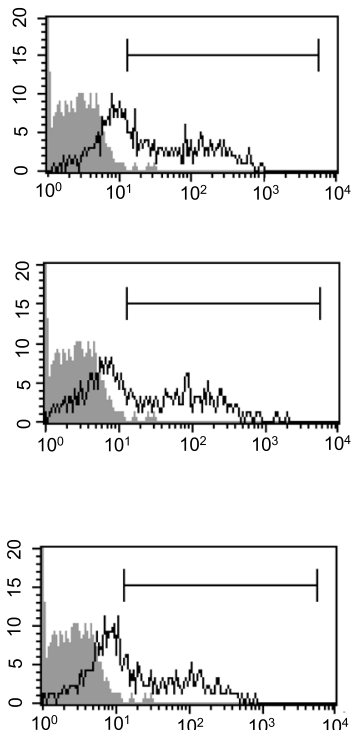

B

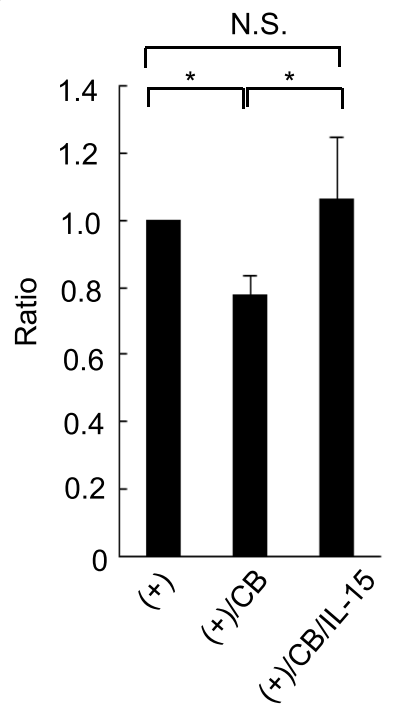

Fig. 4 The expression level of granzyme B in CD8 $8^{+}$Iymphocytes. PBMCs were collected from the three experimental groups: cultured with allogenic stimulation, cultured with allogenic stimulation under $C B$ exposure, and cultured with allogenic stimulation under exposure to $C B$ in media supplemented with IL-15. The expression of granzyme B was analyzed by FCM. a Representative histograms showing intracellular granzyme B expression levels in $\mathrm{CD}^{+}$lymphocytes. Gray-colored histogram shows a non-stained control in each panel. $\mathbf{b}$ In each experimental group, the percentage of granzyme B-positive cells in $\mathrm{CD}^{+}$cells was shown as the ratio to the allogenic-stimulated control. Data are obtained from three independent experiments and are shown as the mean + SD. Significant differences are marked with asterisks $\left({ }^{*} p<0.05\right)$. No significant difference is indicated by N.S.. The control group cultured with allogenic PBMCs without CB is represented by (+), the group cultured with allogenic PBMCs under exposure to $\mathrm{CB}$ is represented by $(+) / \mathrm{CB}$, and the group cultured with allogenic PBMCs under CB exposure with IL-15 is represented by (+)/CB/LL-15

with IL-15 wild-type HER2/neu transgenic mice (NeuT) with respect to mammary carcinogenesis [25]. IL15KO/ NeuT mice showed significantly earlier mammary cancer onset compared with NeuT mice. $\mathrm{CD}^{+}$lymphocytes were significantly lower in IL15KO/NeuT mice compared with mice with wild-type IL-15, which shows similarity in the suppressed response of $\mathrm{CD}^{+}$lymphocytes upon exposure to $\mathrm{CB}$ asbestos. As shown in another study [26], IL- $15^{-1-}$ mice have increased lung metastasis, whereas IL-15 TG mice and IL-15-treated C57BL/6 mice have decreased lung metastasis compared with control. On the basis of those findings, it is possible that IL-15deficient mice might show an increased incidence of mesothelioma following exposure to asbestos. Future investigations concerning IL-15 gene expression and signaling upon exposure to asbestos and the effect of IL-15 deficiency on mesothelioma using in vitro and in vivo experiments should provide critical information of the relationship between IL-15 and mesothelioma caused by asbestos.

Although the percentage of $\mathrm{CD}^{+} \mathrm{CD}^{+}$and $\mathrm{CD} 3$ negative cells as well as $\mathrm{CD}^{+} \mathrm{CD}^{+}$cells did not decrease upon exposure to $\mathrm{CB}$ (Fig. 2a, $\mathrm{c}$, and e), exposure to $\mathrm{CB}$ caused a significant decrease in the number of $\mathrm{CD}^{+} \mathrm{CD}^{+}$ and CD3-negative cells as well as $\mathrm{CD}^{+} \mathrm{CD}^{+}$cells (Fig. 2d and f), indicating that asbestos exposure caused damage in $\mathrm{CD}^{+} \mathrm{CD}^{+}$cells and other cells. In contrast, the effect of IL-15 addition differed among the cell populations examined. The addition of IL-15 significantly and partially restored the asbestos-induced decrease in the number of $\mathrm{CD}^{+} \mathrm{CD}^{+}$cells, but not of $\mathrm{CD}^{+} \mathrm{CD}^{+}{ }^{+}$or $\mathrm{CD} 3$-negative cells (Fig. 2b, d, and f). These results suggest that restoration of the asbestos-induced decrease in the number of $\mathrm{CD}^{+} \mathrm{T}$ cells might depend upon direct action of IL-15 on those cells rather than any indirect action mediated by $\mathrm{CD}^{+} \mathrm{CD}^{+}$or CD3-negative cells. Those findings are consistent with a previous study which showed that $\mathrm{CD} 8^{+} \mathrm{T}$ lymphocyte levels consistently decreased relative to $\mathrm{CD} 4^{+}$ $\mathrm{T}$ lymphocytes in both spleen and lymph nodes of $I L$ $15 \mathrm{R}^{-/-}$mice [27]. IL-15 is regarded as a key cytokine not only of CD8 T cells, but also of DC, macrophage, NK, and NKT cells $[28,29]$. A discussion of this issue is described later.

As described above, the altered expression of cell surface markers was not restored by exogenously added IL-15. On the other hand, treatment with IL-15 led to recovery of $\mathrm{CD}^{+} \mathrm{T}$ cell proliferation and the asbestosinduced decreasing trend in percentage of granzyme $\mathrm{B}^{+}$ cells in proliferating CFSE-negative $\mathrm{CD}^{+}$cells, which were partially and completely restored, respectively. This 
A

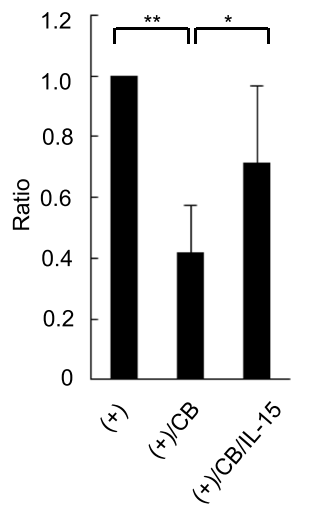

B

$(+)$
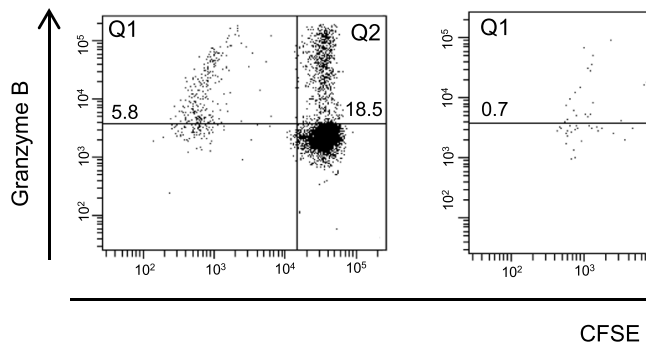

$(+) / C B$

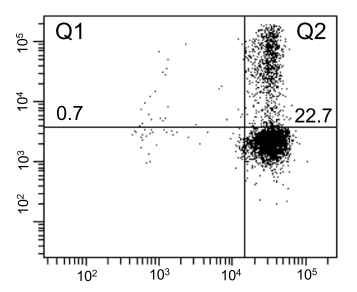

CFSE
$(+) / C B / L-15$

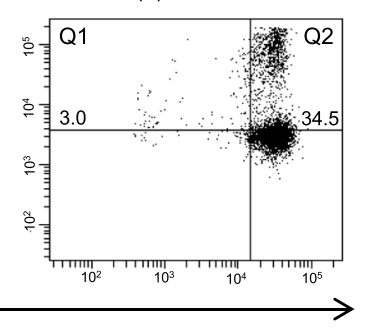

C
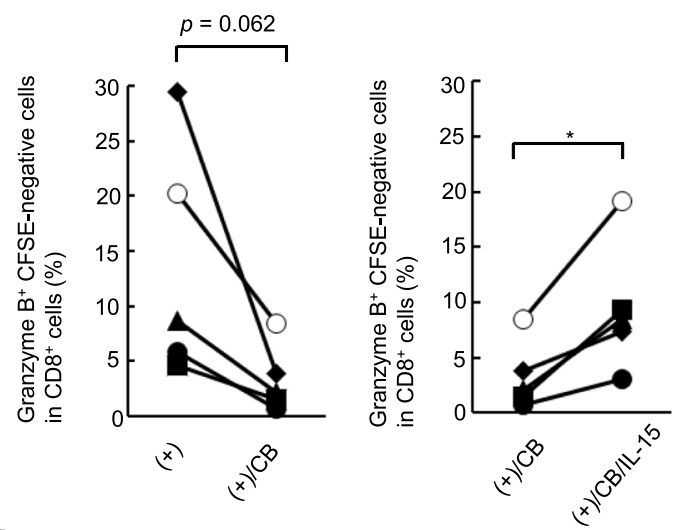

D
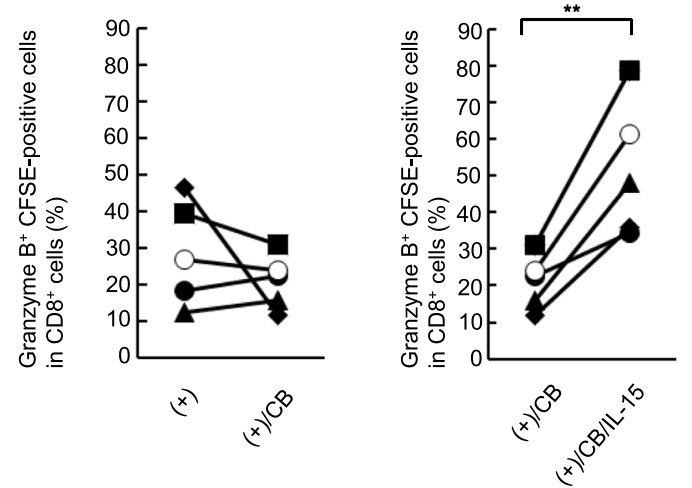

Fig. 5 (See legend on next page.) 


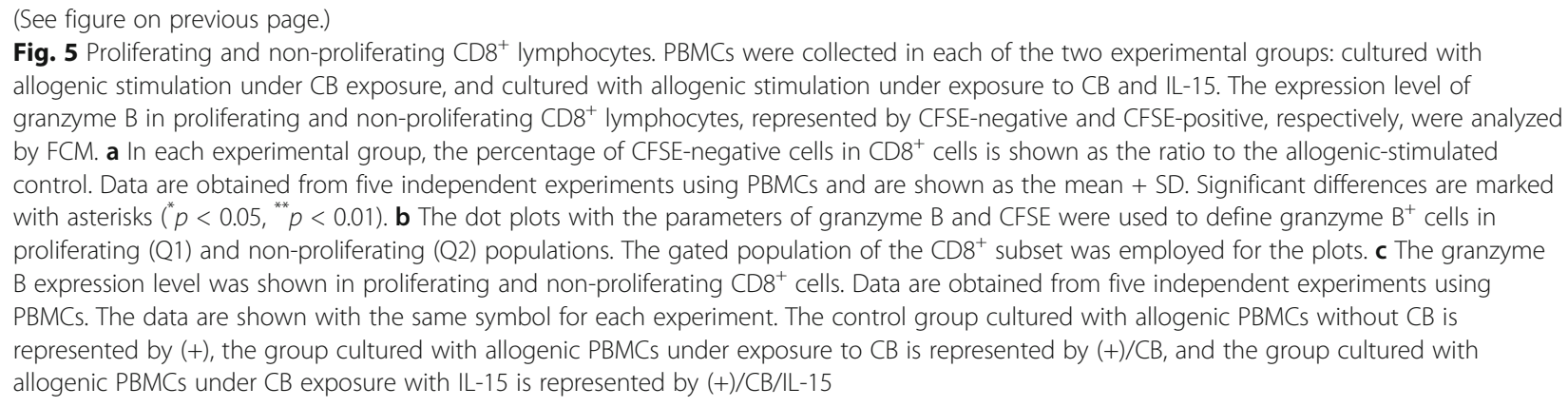

led us to postulate that asbestos-induced suppression of CTL function might be restored by supplementation with IL-15, which is not the same as simply providing conditions without asbestos. In fact, in addition to contributing towards the generation of primary and memory antigen-specific $\mathrm{CD}^{+} \mathrm{T}$ cells [15], IL-15 is known to induce antigen-independent expansion in both naïve as well as non-naive $\mathrm{CD}^{+} \mathrm{T}$ cells, where naïve cells showed down-modulation of CD45RA, while those nonnaïve showed up- or down-modulation of CD45RA [30]. Moreover, IL-15 mediates antigen-independent cell proliferation to maintain memory-phenotype $\mathrm{CD}^{+} \mathrm{T}$ cells [31]. Thus, IL-15 contributes to augmentation of CTL functions beyond the framework of naïve and memory cell populations. These findings have contributed towards efforts aimed at the understanding of the influence of exogenously added IL-15 on the MLR following exposure to asbestos. In preliminary experiments, we confirmed that allogenic stimulation increased levels of proliferating CFSE-negative granzyme $\mathrm{B}^{+}$cells rather than non-proliferating cells. Additionally, exogenously added IL-15 almost doubled the percentage of nonproliferating CFSE-positive granzyme $\mathrm{B}^{+}$cells in asbestosexposed cultures with allogenic stimulation compared with control cultures subjected only to allogenic stimulation in 4 of the 5 experiments. Thus, allogenic stimulation induced proliferating granzyme $\mathrm{B}^{+}$cells, whereas IL-15 supplementation induced non-proliferating granzyme $\mathrm{B}^{+}$ cells in the culture with allogenic stimulation following exposure to asbestos. Therefore, it is possible that IL-15 might induce a different response from antigen-mediated proliferation given the increase in granzyme $\mathrm{B}$ during the MLR.

$\mathrm{CD}^{+}$lymphocytes from cultures treated with IL-15 and asbestos showed the same level of granzyme B as those cells from cultures subjected only to allogenic stimulation, as shown in Fig. 4. Treatment with IL-15 also led to partial increases in proliferation of $\mathrm{CD}^{+}$ lymphocytes. Tamang and coworkers reported that $\mathrm{CD}^{+} \mathrm{T}$ cells can be activated to express granzyme $\mathrm{B}$ and engage in proliferation by treatment with IL-15 in the absence of antigens. Such antigen-independent activation of T cells is known as "bystander-activation", and the mechanism involved in this process might have achieved recovery of granzyme B expression and partial recovery of $\mathrm{CD}^{+}$lymphocyte proliferation in cultures supplemented with IL-15 [32]. Additionally, as shown in Fig. 5, most of the $\mathrm{CD}^{+}$lymphocytes in the culture comprised non-proliferating cells, which exhibited an increase in the percentage of granzyme $\mathrm{B}^{+}$cells in response to treatment with IL-15. This finding suggests possible activation of lymphocytes mediated through IL15 stimulation of other cell populations including monocyte/macrophage, dendritic, NK, and NKT cells. As mentioned above, IL-15 can function in a variety of cell types and cell populations including $\mathrm{CD}^{+} \mathrm{T}$ cells. In fact, IL-15 plays a critical role in the development and survival of NK and NKT cells [29], and loss of IL-15 or IL-15R $\alpha$ results in deficiency of NK and NKT cells [33]. Additionally, in vitro experiments have shown that addition of IL-15 restored IL12R $\beta 1$ gene expression in dendritic cells derived from IL-15KO mice [34]. Those macrophage, dendritic, NK, and NKT cells activated by exogenous IL-15 might contribute to enhanced function in non-proliferating $\mathrm{CD}^{+}$lymphocytes as well as proliferating cells in an indirect manner. Further investigation of cell populations other than $\mathrm{CD}^{+}$lymphocytes and of the functional properties of those populations will contribute towards an understanding of the mechanism of the suppressive effect of asbestos exposure on the differentiation of CTLs.

IL-7 also plays a role in various CTL functions as well as IL-2 and IL-15. All of these are members of the common gamma chain $(\gamma \mathrm{c})$ receptor family and share the same signaling machinery with JAK1/JAK3. However, those cytokines act differently at each stage of the immune response [16]. IL-2 and IL-15 function at the shared stage of clonal expansion of T cells, whereas IL-7 plays a role in homeostatic expansion of naïve $\mathrm{T}$ cells. Additionally, both IL-15 and IL-7 contribute to proliferation and survival of memory $\mathrm{T}$ cells, and IL-15 supports DC-T cell interactions in initiation of the immune response. In our previous study, it was found that exogenous supplementation of IL-2 could augment the 
cytotoxicity of asbestos-exposed $\mathrm{CD}^{+}$lymphocytes and percentage of granzyme $\mathrm{B}^{+}$cells during MLR culture, which represents an in vitro model for the immune response that includes initiation and clonal expansion, but not expansion of naïve cells or maintenance of memory cells. Additionally, CD122 and $\gamma c$ are shared between IL-2 and IL-15. All of the aforementioned data suggest that IL15 is an appropriate target of investigation in studies together with IL-2 supplementation. Therefore, the present study involved the use of exogenous supplementation of IL-15 during MLR cultures exposed to asbestos.

\section{Conclusion}

Our present investigation demonstrated that addition of IL-15 completely restored the expression of granzyme B and partially restored the proliferation of asbestosexposed $\mathrm{CD}^{+}$lymphocytes. This effect was greater than that observed with the addition of IL-2, suggesting that CTLs induced upon exposure to asbestos possess dysfunctional machinery that can be partly compensated by IL-15 supplementation. The finding has motivated us to engage in efforts to identify molecules that could be employed to improve suppressed CTL immune responses resulting from exposure to asbestos. This approach could facilitate delineation of the mechanism responsible for asbestos-induced suppression of CTL function. These issues will be examined in future studies.

\section{Abbreviations}

MLR: Mixed lymphocyte reaction; CTLs: Cytotoxic T lymphocytes; IL-2: Interleukin2; IL-15: Interleukin-15; PBMCs: Peripheral blood mononuclear cells; CFSE: Carboxyfluorescein diacetate succinimidyl ester; DCs: Dendritic cells; CB: Chrysotile B; Abs: Antibodies; PC5: Phycoerythrin-cychrome 5; FITC: Fluorescein isothiocyanate; PE: Phycoerythrin; FCM: Flow cytometry; RPE: R-phycoerythrin

\section{Acknowledgements}

We thank Ms. Tamayo Hatayama and Shoko Yamamoto for their technical assistance.

\section{Authors' contributions}

Conception and design: NK-T, YN, and TO. Analysis and interpretation: all authors. Drafting of the manuscript: NK-T and YN. The author(s) read and approved the final manuscript.

\section{Funding}

The work was supported by JPSS KAKENHI Grants (16K09114) and Kawasaki Medical School Project Grant (27B068, 28B008).

\section{Availability of data and materials}

The data used to support the findings of this study are available from the corresponding author upon reasonable request.

\section{Declarations}

Ethics approval and consent to participate

All blood samples were taken from healthy volunteers who provided informed consent. The project was approved by the Institutional Ethics Committees of Kawasaki Medical School.

Consent for publication

Not applicable.

\section{Competing interests}

The authors declare that they have no conflicts of interest.

\section{Author details}

'Department of Hygiene, Kawasaki Medical School, Kurashiki 701-0192, Japan. ${ }^{2}$ Department of Life Sciences, Faculty of Life and Environmental Sciences, Prefectural University of Hiroshima, 727-0023, Shobara, Japan.

Received: 14 November 2020 Accepted: 22 March 2021

Published online: 19 April 2021

\section{References}

1. Sporn TA, Roggli, V L. Mesothelioma. In Roggli VL, Oury TD, Sporn TA, Editors. Pathology of asbestos-associated diseases. New York: SpringerVerlag; 2004. p.104-168.

2. Mossman BT, Kamp DW, Weitzman SA. Mechanisms of carcinogenesis and clinical features of asbestos-associated cancers. Cancer Invest. 1996;14(5): 466-80. https://doi.org/10.3109/07357909609018904.

3. Stayner $L$, Welch $L S$, Lemen R. The worldwide pandemic of asbestos-related diseases. Annu Rev Public Health. 2013;34(1):205-16. https://doi.org/10.114 6/annurev-publhealth-031811-124704.

4. Leong SL, Zainudin R, Kazan-Allen L, Robinson BW. Asbestos in Asia. Respirology. 2015;20(4):548-55. https://doi.org/10.1111/resp.12517.

5. Carbone M, Adusumilli PS, Alexander HR Jr, Baas P, Bardelli F, Bononi A, et al. Mesothelioma: scientific clues for prevention, diagnosis, and therapy. CA Cancer J Clin. 2019;69(5):402-29. https://doi.org/10.3322/caac.21572.

6. Dusinská M, Collins A, Kazimírová A, Barancoková M, Harrington V, Volkovová K, et al. Genotoxic effects of asbestos in humans. Mutat Res. 2004;553(1-2):91-102. https://doi.org/10.1016/j.mrfmmm.2004.06.027.

7. Topinka J, Loli $\mathrm{P}$, Georgiadis $\mathrm{P}$, Dusinská M, Hurbánková M, Kováciková $Z$, et al. Mutagenesis by asbestos in the lung of lambda-lacl transgenic rats. Mutat Res. 2004;553(1-2):67-78. https://doi.org/10.1016/j.mrfmmm.2 004.06.023.

8. McDonald AD, McDonald JC. Mesothelioma after crocidolite exposure during gas mask manufacture. Environ Res. 1978;17(3):340-6. https://doi. org/10.1016/0013-9351(78)90038-5.

9. Selikoff IJ, Hammond EC, Seidman H. Mortality experience of insulation workers in the United States and Canada, 1943--1976. Ann N Y Acad Sci 1979; 330: 91-116, Mortality experience of insulation workers in the United States and Canada, 1943-1976, 1 Health Hazard, DOI: https://doi.org/1 0.1111/j.1749-6632.1979.tb18711.x.

10. Selikoff IJ, Hammond EC, Seidman H. Latency of asbestos disease among insulation workers in the United States and Canada. Cancer 1980; 46: 27362740, 12, DOl: https://doi.org/10.1002/1097-0142(19801215) 46:12<2736:AIDCNCR2820461233>3.0.CO;2-L.

11. Nishimura Y, Miura Y, Maeda M, Kumagai N, Murakami S, Hayashi H, Fukuoka K, Nakano T, Otsuki T Impairment in cytotoxicity and expression of NK cell-activating receptors on human NK cells following exposure to asbestos fibers. Int J Immunopathol. Pharmacol. 2009; 22:579-590, Impairment in Cytotoxicity and Expression of NK Cell- Activating Receptors on Human NK Cells following Exposure to Asbestos Fibers, 3, DOl: https:// doi.org/10.1177/039463200902200304.

12. Maeda M, Nishimura $Y$, Hayashi H, Kumagai N, Chen Y, Murakami S, et al. Reduction of CXC chemokine receptor 3 in an in vitro model of continuous exposure to asbestos in a human T-cell line, MT-2. Am J Respir Cell Mol Biol. 2011;45(3):470-9. https://doi.org/10.1165/rcmb.2010-02130C.

13. Kumagai-Takei N, Nishimura Y, Maeda M, Hayashi H, Matsuzaki H, Lee S, et al. Effect of asbestos exposure on differentiation of cytotoxic $T$ lymphocytes in mixed lymphocyte reaction of human peripheral blood mononuclear cells. Am J Respir Cell Mol Biol. 2013;49(1):28-36. https://doi. org/10.1165/rcmb.2012-0134OC.

14. Kumagai-Takei N, Nishimura Y, Matsuzaki H, Lee S, Yoshitome K, Hayashi $H$, et al. The suppressed induction of human mature cytotoxic T lymphocytes caused by asbestos is not due to interleukin-2 insufficiency. I Immunol Res. 2016. https://doi.org/10.1155/2016/7484872.

15. Schluns KS, Williams K. Ma A, Zheng XX, Lefrançois L. Requirement for IL-15 in the generation of primary and memory antigen-specific CD8 T cells. J. Immunol. 2002; 168:4827-4831, 10, DOI: https://doi.org/10.4049/jimmunol.1 68.10.4827. 
16. Schluns KS, Lefrançois L. Cytokine control of memory T-cell development and survival. Nat. Rev. Immunol. 2003;3(4):269-79. https:// doi.org/10.1038/nri1052.

17. Bluman EM, Schnier GS, Avalos BR, Strout MP, Sultan H, Jacobson FW, et al. The c-kit ligand potentiates the allogenic mixed lymphocyte reaction. Blood. 1996;88(10):3887-93. https://doi.org/10.1182/blood.V88.10.3887. bloodjournal88103887.

18. Kohyama N, Shinohara Y, Suzuki Y. Mineral phase and some reexamined characteristics of the International Union Against Cancer standard asbestos samples. Am J Ind Med 1996; 30:515-528, 5, DOI: https://doi.org/10.1002/ (SICI) 1097-0274(199611)30:5<515::AID-AJIM1>3.0.CO;2-S.

19. Hamann D, Roos MT, van Lier RA. Faces and phases of human CD8+ T-cell development. Immunol Today. 1999;20(4):177-80. https://doi.org/10.1016/ S0167-5699(99)01444-9.

20. Tomiyama H, Matsuda T, Takiguchi M. Differentiation of human CD8+ T cells from a memory to memory/effector phenotype. J Immunol. 2002; 168(11):5538-50. https://doi.org/10.4049/jimmunol.168.11.5538.

21. Redmond WL, Ruby CE, Weinberg AD. The role of OX40-mediated costimulation in T cell activation and survival. Crit. Rev. Immunol. 2009;29(3): 187-201. https://doi.org/10.1615/CritRevlmmunol.v29.i3.10.

22. Duitman EH, Orinska Z, Bulanova E, Paus R, Bulfone-Paus S. How a cytokine is chaperoned through the secretory pathway by complexing with its own receptor: lessons from interleukin-15 (IL-15) / IL-15 receptor alpha. Mol Cell Biol. 2008;28(15):4851-61. https://doi.org/10.1128/MCB.02178-07.

23. Dodson RF, Williams MG Jr, Corn CJ, Brollo A, Bianchi C. A comparison of asbestos burden in lung parenchyma, lymph nodes, and plaques. Ann N Y Acad Sci. 1991;643(1 The Third Wav):53-60. https://doi.org/10.1111/j.17496632.1991.tb24443.x

24. Dodson RF, O'Sullivan MF, Brooks DR, Bruce JR. Asbestos content of omentum and mesentery in nonoccupationally exposed individuals. Toxicol Ind Health. 2001;17(4):138-43. https://doi.org/10.1191/0748233701th101oa.

25. Croci S, Nanni P, Palladini A, Nicoletti G, Grosso V, Benegiamo G, et al. Interleukin-15 is required for immunosurveillance and immunoprevention of HER2/neu-driven mammary carcinogenesis. Breast Cancer Res. 2015;17(1):70, https://doi.org/10.1186/s13058-015-0588-x.

26. Gillgrass A, Gill N, Babian A, Ashkar AA. The absence or overexpression of IL15 drastically alters breast cancer metastasis via effects on NK cells, CD4 T cells, and macrophages. J. Immunol. 2014;193(12):6184-91. https://doi.org/1 0.4049/jimmunol.1303175.

27. Lodolce JP, Boone DL, Chai S, Swain RE, Dassopoulos T, Trettin S, et al. IL-15 receptor maintains lymphoid homeostasis by supporting lymphocyte homing and proliferation. Immunity. 1998;9(5):669-876. https://doi.org/10.1 016/s1074-7613(00)80664-0.

28. Pin-Yu P, Lichy JH, Waldmann TA, Perera LP. The role of interleukin-15 in inflammation and immune response to infection: implications for its therapeutic use. Microbes. Infect. 2012;14(3):247-61. https://doi.org/10.1016/ j.micinf.2011.10.006.

29. Ohteki T. Critical role for IL-15 in innate immunity. Curr Mol Med. 2002;2(4): 371-80. https://doi.org/10.2174/1566524023362519.

30. Alves NL, Hooibrink B, Arosa FA, van Lier RA. IL-15 induces antigenindependent expansion and differentiation of human naive CD8+ T cells in vitro. Blood. 2003;102(7):2541-6. https://doi.org/10.1182/blood-2 003-01-0183.

31. Boyman O. Bystander activation of CD4+ T cells. Eur J Immunol. 2010;40(4): 936-9. https://doi.org/10.1002/eji.201040466.

32. Tamang DL, Redelman D, Alves BN, Vollger L, Bethley C, Hudig D, et al. Induction of granzyme B and T cell cytotoxic capacity by IL-2 or IL-15 without antigens: multiclonal responses that are extremely lytic if triggered and short-lived after cytokine withdrawal. Cytokine. 2006;36(3-4):148-59. https://doi.org/10.1016/j.cyto.2006.11.008.

33. Williams NS, Klem J, Puzanov IJ, Sivakumar PV, Schatzle JD, Bennett M, et al. Natural killer cell differentiation: insights from knockout and transgenic mouse models and in vitro systems. Immunol Rev. 1998;165(1):47-61. https://doi.org/10.1111/j.1600-065X.1998.tb01229.x.

34. Ohteki T, Suzue K, Maki C, Ota T, Koyasu S. Critical role of IL-15-IL-15R for antigen-presenting cell functions in the innate immune response. Nat Immunol. 2001;2(12):1138-43. https://doi.org/10.1038/ni729.

\section{Publisher's Note}

Springer Nature remains neutral with regard to jurisdictional claims in published maps and institutional affiliations.

Ready to submit your research? Choose BMC and benefit from:

- fast, convenient online submission

- thorough peer review by experienced researchers in your field

- rapid publication on acceptance

- support for research data, including large and complex data types

- gold Open Access which fosters wider collaboration and increased citations

- maximum visibility for your research: over $100 \mathrm{M}$ website views per year

At BMC, research is always in progress.

Learn more biomedcentral.com/submissions 